\title{
OCCURRENCE AND REDESCRIPTION OF THRYSSA SETIROSTRIS (BROUSSONET, 1782) (CLUPIFORMES, ENGRAULIDAE) FROM IRAQI MARINE WATER
}

\author{
N. R. Khamees* T. K. Adday and J. M. Abed \\ Department of Fisheries and Marine Resources, College of Agriculture, \\ University of Basrah,Basrah, Iraq \\ *Corresponding author: khamees54@yahoo.com
}

Received Date:19 March 2018

\section{ABSTRACT}

Nine fish specimens of Thryssa setirostris (Broussonet, 1782) were collected from the Arabian Gulf, during the period from July 2015 to April 2016. Because of the scarcity of this fish and overlapping and ambiguous of its taxonomic characters with other Thryssa spp., a detailed taxonomic study was conducted. The present study includes the most important meristic and morphometric characteristics.

The mean of the total length of the specimens was $149.67 \mathrm{~mm}$; dorsal fin consists of 12 rays, anal fin with 34-37 rays and pectoral fin with 12-13 rays; Gill rakers were 4 upper,1 medial and10 lower. The most important character that isolates $T$. setiristis from other close Thryssa spp. is the maxilla which is considered very long and reach beyond the tip of the pectoral fin.

\section{INTRODUCTION}

Clupeid fishes is a group of the most important global commercial fish, which include wellknown fishes as herrings, sardines and anchovies (Li and Orti, 2007); According to Froese and Pauly (2018) this group is divided into seven families Dentricipidae, Pristigasteridae, Engraulidae, Clupeidae, Chirocentridae, Dussumieriidae and Sundusalangidae.

Engraulidae are distributed in all marine habitats, extended from $60^{\circ} \mathrm{N}$ to $50^{\circ} \mathrm{S}$. They are abundant along the Indo-Pacific coasts, Atlantic and Indian oceans (Whitehead et al., 1988; Froese and Pauly, 2018). The engrulids characterized by having prominent snout (overhanging the mouth), single dorsal fin without spines, maxilla well extends behind the eye and scutes are present in most species (Young et al., 1994; Carpenter et al., 1997). This family comprises 17 valid genera, including Thryssa. This genus has 31 nominal species, mostly distributed in Indo-Pacific regions, and the Indian Ocean including Gulf of Oman; they are abundant in the Arafura Sea (Froese and Pauly, 2018). Kuronuma and Abe (1972. 1986) mentioned Thryssa mystax in both studies, while the latter mentioned $T$, purava, $T$. malabarica and T. hamiltonii in the Arabian gulf. Carpenter et al. (1997) mentioned five species vis., T. baelama, T. dussumieri, T. hamiltonii, T. vitrirostris and T. whiteheadi. Bishop (2003) mentioned six species of Engraulidae off Kuwait, including three species of Thryssa but he didn't mention T. setirostris. Al-Faisal (2012) published a taxonomic study of three species of Thryssa including T. whiteheadi, T. mystax and T. vitrirostris. Six species of Thryssa were recorded in Iraq, including T. setirostris (Nader and Jawdat, 1977; Coad, 1991; 


\section{Occurrence and redescription of Thryssa setirostris}

Adday, 2013). The present study deals with the occurrence of this rare species in the Iraqi marine water and detailed merestic and morphometric measurements.

\section{MATERIALS AND METHODS}

Nine specimens of $T$. setirostris (Broussonet,1782) were collected during the period from July 2015 till April 2016 from the north western Arabian Gulf $\left(48^{\circ} 44^{\prime}\right.$ to $48^{\circ} 46^{\prime} \mathrm{N} ; 29^{\circ} 46^{\prime}$ to $29^{\circ} 47^{\prime} \mathrm{E}$ ); Fish specimens were caught by means of a trawl net, and kept in ice, then transferred to the laboratory where it was examined as soon as possible. Morphometric and meristic measurements were achieved according to Wangratana (1987). Fine characters were detected under Meiji dissecting microscope.

Total, fork and standard lengths were measured by scale measurement to the nearest 0.1 $\mathrm{mm}$, lengths of different morphometric terms were measured using digital vernier; the ranges of measurements were given followed by means between parenthesis.

\section{RESULTS AND DISCUSSION}

Thirty nine parameters were detected from nine specimens of long jaw thryssa Thryssa setirostris (Pl. 1) from the Iraqi marine water.

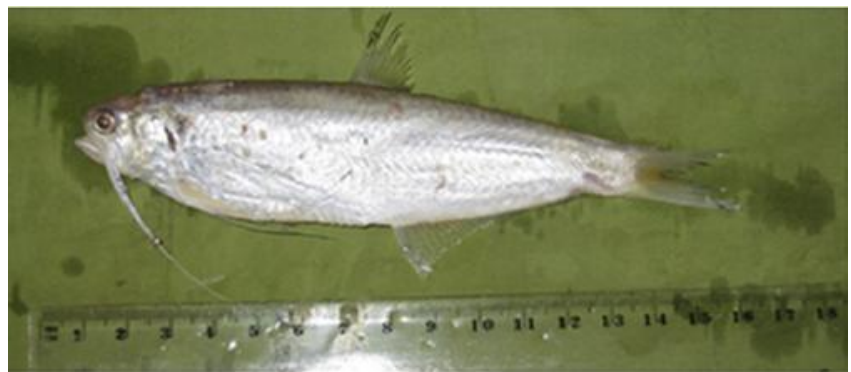

Plate (1):Thryssa setirostris, $125 \mathrm{~mm}$ in standard length.

The total length of the specimens ranged from 116-165 (149.67) mm; dorsal fin consists of 12 rays; anal fin with 34-37 rays (Tab. 1). 
Khamees et al.

Table(1)*: Meristic and morphometric characters of T. setirostris.

\begin{tabular}{|c|c|c|c|c|c|c|c|c|c|}
\hline $\begin{array}{l}\text { Biometric } \\
\text { characters }\end{array}$ & 1 & 2 & 3 & 4 & 5 & 6 & 7 & 8 & 9 \\
\hline Total length & 154 & 116 & 148 & 152 & 150 & 153 & 155 & 154 & 165 \\
\hline Standard length & 126 & 95 & 121 & 128 & 121 & 124 & 127 & 125 & 132 \\
\hline Forked length & 135 & 104 & 130 & 134 & 131 & 135 & 135 & 135 & 144 \\
\hline Body d. d. & 34.2 & 24.6 & 32.4 & 36.1 & 33.2 & 33.6 & 34.5 & 33.3 & 33.8 \\
\hline Body d. a. & 30.7 & 22.0 & 30.3 & 30.9 & 30.8 & 29.5 & 31.2 & 31.5 & 30.6 \\
\hline Body width & 12.1 & 8.6 & 11.2 & 12.0 & 11.5 & 11.6 & 12.2 & 11.2 & 11.3 \\
\hline Head length & 24.8 & 18.9 & 25.3 & 25.3 & 25.5 & 23.6 & 25.5 & 26.5 & 27.4 \\
\hline Head depth & 23.2 & 16.8 & 21.7 & 22.7 & 21.6 & 21.2 & 22.2 & 12 & 22.5 \\
\hline Head width & 9.3 & 7.8 & 10.4 & 11.3 & 10.5 & 10.1 & 10.8 & 10 & 10.4 \\
\hline Int. orb. w. & 5.5 & 4.7 & 5.5 & 6.2 & 5.6 & 5.8 & 5.8 & 5.9 & 5.8 \\
\hline Eye diameter & 6.5 & 5.9 & 6.8 & 6.7 & 6.6 & 6.9 & 7.2 & 7.1 & 7.0 \\
\hline Snout length & 2.53 & 2.4 & 2.5 & 3.1 & 3.01 & 3.3 & 3.4 & 3.5 & 3.4 \\
\hline Post orb. length & 16.7 & 10.7 & 15.4 & 16.7 & 15.8 & 15.4 & 16.3 & 16.4 & 17.5 \\
\hline Up. jaw length & 13.7 & 11.3 & 13.1 & 13.5 & 16 & 14.2 & 13.7 & 12.9 & 15.2 \\
\hline Lo. jaw length & 13.1 & 10.8 & 12.5 & 13.0 & 14.9 & 12.4 & 12.3 & 11.8 & 13.5 \\
\hline Dorsal fin b. 1 . & 11.9 & 11.6 & 12.3 & 12.8 & 12.3 & 12.5 & 14.3 & 12.5 & 13.4 \\
\hline Dorsal fin h. & 23.4 & 20.8 & 23.0 & 23.2 & 23.7 & 23.0 & 25.5 & 22.5 & 25.8 \\
\hline Pect. fin b. 1. & 8.1 & 4.0 & 6.7 & 6.8 & 8.0 & 7.0 & 7.2 & 6.9 & 8.5 \\
\hline Pectoral high & 24.5 & 19.3 & 23.3 & 24.5 & 23.8 & 23.4 & 26.1 & 26.2 & 28.5 \\
\hline Anal fin b. 1. & 38.2 & 31.0 & 36.5 & 38.2 & 40.5 & 38.5 & 40.2 & 38.6 & 38.7 \\
\hline Anal fin high & 17.3 & 13.9 & 16.4 & 17.2 & 17.8 & 17.2 & 18.3 & 17.6 & 19.5 \\
\hline Pre-dorsal d. & 60.8 & 43.8 & 62 & 65 & 16.7 & 62.2 & 62 & 63.2 & 63.9 \\
\hline Pre-pelvic d. & 46.9 & 37.7 & 48.2 & 48.3 & 46.3 & 47.7 & 50 & 49.2 & 54.4 \\
\hline Pre-pectoral d. & 24.4 & 20.2 & 23.6 & 23.3 & 24.4 & 22.7 & 23.4 & 23 & 26.8 \\
\hline Pre-anal length & 74.3 & 59.2 & 71.9 & 73.3 & 74.2 & 75.7 & 78.4 & 72.5 & 82.2 \\
\hline Pre-anus length & 71.0 & 56.4 & 68.2 & 70 & 72.2 & 72.4 & 74.8 & 69.1 & 79.0 \\
\hline Pelvic anal d. & 26.6 & 18.2 & 24.4 & 23.6 & 24.5 & 23.3 & 27 & 22.8 & 28.3 \\
\hline Caudal p. 1. & 13.0 & 10.8 & 13.1 & 13.4 & 11.6 & 11.9 & 12 & 12.4 & 12.9 \\
\hline Caudal p. d. & 13.2 & 10.0 & 12.8 & 13.3 & 12.8 & 12.4 & 13.1 & 13.0 & 13.1 \\
\hline Dorsal fin rays & 12 & 12 & 12 & 12 & 12 & 12 & 12 & 12 & 12 \\
\hline Anal fin rays & 34 & 37 & 36 & 36 & 34 & 34 & 34 & 36 & 36 \\
\hline Pect. fin rays & $\mathrm{I}+13$ & $\mathrm{I}+12$ & $\mathrm{I}+12$ & $\mathrm{I}+12$ & $\mathrm{I}+12$ & $\mathrm{I}+12$ & $\mathrm{I}+12$ & $\mathrm{I}+12$ & $\mathrm{I}+12$ \\
\hline Pelvic fin rays & $\mathrm{I}+6$ & $\mathrm{I}+6$ & $\mathrm{I}+6$ & $\mathrm{I}+6$ & $\mathrm{I}+6$ & $\mathrm{I}+6$ & $\mathrm{I}+6$ & $\mathrm{I}+6$ & $\mathrm{I}+6$ \\
\hline Total Scutes & 27 & 25 & 27 & 27 & 26 & 26 & 26 & 26 & 26 \\
\hline Pre pel. scutes & 16 & 16 & 17 & 17 & 17 & 17 & 17 & 17 & 17 \\
\hline Bran. Steg. rays & $12 ?$ & 12 & 12 & 12 & 12 & 12 & 12 & 12 & 12 \\
\hline Gill rackers & & $4,1,10$ & $4,1,10$ & $4,1,10$ & $4,1,10$ & & $4,1,10$ & & \\
\hline Maxilla length & 62.2 & 52.2 & 64.1 & 72.8 & 66.4 & 63.1 & 7.1 .8 & 68.6 & 73.2 \\
\hline Pv length & 16.8 & 11.6 & 15.6 & 13.3 & 15.8 & 13.4 & 13.9 & 15.5 & 17.2 \\
\hline
\end{tabular}

* Body d. d.= body depth at dorsal fin; Body d. a.= body depth at anal fin; Int. orb. w.= interorbital width; Post orb. length= postorbital length; Up. jaw length= upper jaw length; Lo. jaw length $=$ lower jaw length; Dorsal fin b. $1 .=$ dorsal fin base length; Dorsal fin $\mathrm{h} .=$ dorsal fin high; Pect. fin b. l.= pectoral fin base length; Anal fin b. 1.= anal fin base length; Pre-dorsal $\mathrm{d} .=$ pre-dorsal fin body depth; Pre-pelvic $\mathrm{d} .=$ pre-pelvic fin body depth; Pre-pectoral $\mathrm{d} .=$ prepectoral fin body depth; Caudal p. $1 .=$ caudal peduncle length; Caudal p. $d .=$ caudal peduncle depth; Pect. fin rays= pectoral fin rays; Pre pel. scutes $=$ number of pre-pelvic scutes; Bran. Steg. Rays $=$ Number of branchiostegal rays; Pv. Length= Pelvic fin length. 
Occurrence and redescription of Thryssa setirostris

Table (2): The ratio of parameters of T. setirosris to standard length

\begin{tabular}{|l|c|c|c|c|}
\hline \multicolumn{1}{|c|}{ Parameters \% } & Min. & Max. & Average & SD \\
\hline Total L./Stan. L & 118.750 & 125.000 & 122.555 & 1.739 \\
\hline Fork L / Stan. L & 105.469 & 109.474 & 107.783 & 1.328 \\
\hline Body d D / Stan. L & 25.606 & 28.203 & 26.885 & 0.784 \\
\hline Body d A / Stan. L & 23.158 & 25.455 & 24.322 & 0.837 \\
\hline Body w / Stan. L & 8.561 & 9.606 & 9.253 & 0.343 \\
\hline Head L / Stan. L & 19.032 & 21.200 & 20.266 & 0.747 \\
\hline Head D / Stan. L & 17.045 & 18.413 & 17.693 & 0.435 \\
\hline Head W / Stan. L & 7.381 & 8.828 & 8.247 & 0.457 \\
\hline Interorbit W / Stan. L & 4.365 & 4.947 & 4.632 & 0.192 \\
\hline Eye diameter / Stan. L & 5.159 & 6.211 & 5.544 & 0.315 \\
\hline Snout L / Stan. L & 2.008 & 2.800 & 2.469 & 0.270 \\
\hline Post Orb. L / Stan. L & 11.263 & 13.258 & 12.776 & 0.628 \\
\hline Upper Jaw L / Stan. L & 10.320 & 11.895 & 11.041 & 0.505 \\
\hline Lower Jaw L / Stan. L & 9.440 & 11.368 & 10.252 & 0.558 \\
\hline Dorsal fin b. L / Stan. L & 9.444 & 12.211 & 10.386 & 0.831 \\
\hline Dorsal Height / Stan. L & 18.000 & 21.895 & 19.262 & 1.210 \\
\hline Pect. Fin b. L. / Stan. L & 4.211 & 6.612 & 5.708 & 0.736 \\
\hline Pectral height / Stan. L & 18.871 & 21.591 & 19.978 & 0.924 \\
\hline Anal fin b. L. / Stan. L & 29.318 & 33.471 & 31.037 & 1.348 \\
\hline Anal fin height / Stan. L & 13.438 & 14.773 & 14.133 & 0.515 \\
\hline Predorsal D. / Stan. L & 46.105 & 51.240 & 49.480 & 1.702 \\
\hline Prepvelvic D. / Stan. L & 37.222 & 41.212 & 39.017 & 1.220 \\
\hline Pre. Pec. D. / Stan. L & 18.203 & 21.263 & 19.326 & 1.085 \\
\hline Pre. Anal D. / Stan. L & 57.266 & 62.316 & 60.261 & 1.892 \\
\hline Pre Anus D. / Stan. L & 54.688 & 59.848 & 57.650 & 1.991 \\
\hline Pelvic anal D. / Stan. L & 18.240 & 21.439 & 19.872 & 1.252 \\
\hline Caudal p. L. / Stan. L & 9.449 & 11.368 & 10.145 & 0.650 \\
\hline Caudal p. D. / Stan. L & 9.924 & 10.579 & 10.354 & 0.240 \\
\hline Maxilla / Stan. L & 49.365 & 56.875 & 54.088 & 2.535 \\
\hline Pelvic length / Stan. L & 10.391 & 13.333 & 12.119 & 1.116 \\
\hline & & & & \\
\hline
\end{tabular}

Total length/ Standard length $122.555 \%$, body depth/standard length $24.322 \%$, head length/standard length $20.266 \%$ (Tab. 2). T. setirostris has very short rounded snout with its tip lay on the equator of the eye, the maxilla being very long, reaches the tip of the pectoral fin (Pl.1).

In general, fish species diversity in the Arabian Gulf is rather irregular, mainly because the deplete of water temperature in winter is also irregular, thus the diversity of individual species in the Gulf may fluctuate from year to another (Krupp and Müller, 1994). The Arabian Gulf is less biologically diverse than the adjacent Indian Ocean due to extreme environmental conditions (Al-Abdulrazzak et al., 2015); the Engraulids are small to moderate size fishes. However, some records refer to considerable fish size (Varghese et al., 2013).

Fricke et al. (2018) mentioned 24 species of Thryssa, all distributed in tropical and subtropical marine environments around the world (Froese and Pauly, 2018); according to 


\section{Khamees et al.}

Carpenter et al. (1997) there are five Thryssa species in the Arabian Gulf excluding $T$. setirostris, this species was firstly recorded in the Gulf by Nader and Jawdat (1977).

There are reports of overlapping and ambiguous taxonomic characters among the species of Engraulidae in general and especially in Thryssa, this might be resulting in misidentification of species and presentation of incorrect data (Ma et al., 2015; Gangan et al., 2016).

The identification of Thryssa species is usually based on combination of some characters such as the length of maxilla which may either being short (reach the preopercular), or medium (reach gill slits), or long (reach base of pectoral fins), or some even very long (reach pelvic fin base or beyond) (Whitehead et al., 1988). In most Thryssa species the first supramaxilla is minute or lost while the second supramaxilla is prominent (Ganga, 2015), those with or without first supramaxilla, and the level of tip of snout with a line drawn through mid-eye as in Plate 1, comprises some species including T. setirostris (Whitehead et al., 1988), T. setirostris differ from other species in this group by having very long maxilla.

Randall (1995) recorded T. setirostris (Broussonet, 1782)from Gulf of Oman, he mentioned the number of rays of anal and pectoral fins which are in the same range with the specimens of the present study ; Moreover, the rays of the dorsal fin in the present study are 12 while in Randall (1995) they were 14-15 (Tab. 3); from the other hand, Ma et al. (2015) mentioned that the dorsal fin of $T$. setirostris (Broussonet, 1782)of Taiwan has 11-12 rays.

Iwatsucki (2013) stated that the meristic characters of fish may varied in different habitats, the dorsal rays of $T$. setirostris (Broussonet, 1782) are different in number from that of T. whiteheadi Wongranata, 1983 and T. vitirostris (Gilchrist \& Thompson, 1908) (Tab. 3), but has the same range of the dorsal rays of $T$. hamiltonii, Gray, 1835 and within the range of the number of rays of the anal fin of the same species (Tab. 2). T. setirostris (Broussonet, 1782)differ from $T$. hamiltonii Gray, 1835 by having very long maxilla (Ganga, 2015), $T$. dussumieri (Valenciennes, 1848) is very close in appearance to T. setirostris (Broussonet, 1782), again the latter is different by having a very long maxilla.

Table (3):Comparative measurements of fin rays and gill rackers of Thryssa spp.

\begin{tabular}{|c|c|c|c|c|c|}
\hline Species & $\begin{array}{c}\text { Dorsal fin } \\
\text { rays }\end{array}$ & $\begin{array}{c}\text { Anal fin } \\
\text { rays }\end{array}$ & $\begin{array}{c}\text { Pectoral fin } \\
\text { rays }\end{array}$ & $\begin{array}{c}\text { Gill } \\
\text { rackers }\end{array}$ & References \\
\hline T. whiteheadi & 13 & $42-46$ & 14 & $18-21$ & Richards, 2008 \\
\hline T. viterostris & $13-15$ & $34-43$ & $13-14$ & $18-24$ & Richards, 2008 \\
\hline T. balamae & $11-12$ & $32-37$ & $13-14$ & $20-24$ & $\begin{array}{c}\text { Young } \text { et al., 1994; } \\
\text { Whitehead } \text { et al., 1988 }\end{array}$ \\
\hline T. hamiltoni & $14-15$ & $32-40$ & $12-13$ & $12-14$ & Richards, 2008 \\
\hline T. seterostris & $14-15$ & $32-39$ & $12-14$ & $10-12$ & Randall, 1995 \\
\hline T. seterostris* & 12 & $34-37$ & $\mathrm{I}+12-13$ & 4.1 .10 & Present study \\
\hline
\end{tabular}

*Species identification confirmed by Dr. Uwe Zajong, Germany. 


\section{ACKNOLEDGMENT}

Thanks are due to Dr. Uwe Zajong of Senckenberg Research Institute and Natural Museum, Germany who confirmed the identity of $T$. setirostris.

\section{LITERATURE CITED}

Adday, T. K. 2013. Parasitic crustaceans of some marine fishes of Basrah province, Iraq. Ph. D. thesis Collage of agriculture. University of Basrah, $302 \mathrm{pp}$.

Al-Abdulrazzak, D., Zeller, D., Belhabib, D., Tesfamichael, D. and Pauly, D. 2015. Total marine fisheries catches in the Persian/Arabian Gulf from 1950 to 2010. Regional Studies in Marine Science, 2: 28-34.

Al-Faisal, A. J. 2012. Taxonomic study of three species of genus Thryssa fishes from Iraqi marine water. Journal Al-Malik Abdul-Azeez for Marine Science. 23 (1): 147-163.

Bishop, J. M. 2003. History and current checklist of Kuwait icthyofauna. Journal of Arid environment, 54: 237-256.

Carpenter, K. E., Krupp, F., Jones, D. A. and Zajonz, U. 1997. The living marine resources of Kuwait, Eastren Saudi Arabia, Bahrain, Qatar and the United Arab Emarates. FAO species identification field guide for fishery purpose, FAO, Rome, XVII + $293 \mathrm{pp}$.

Coad, B. W. 1991. Fishes of the Tigris- Euphrates basin: Acritical checklist. Syllogeus 68, Canadian museum of nature, Ottawa, 49pp.

Fricke, R., Eschmeyer, W. N. and vander Lann, R. (eds.) 2018. Catalog of fishes: Genera, species, references. California Academy of Science, San Francisco, USA. Availableat: http// researcharchive. calademy. org/ research/ ichthyology/ catalog/ fishcatmain. asp. http://www.fishbase.org/identification/SpeciesList.php?genus=Thryssa (Accessed March, 2018).

Froese, R. and Pauly, D. 2018. A Clupiformes. Fish base, world register of marine species. Available at: www. Marine species. (Accessed July, 2018)

Ganga, U. 2015. Aspects of taxonomy and life history traits of engraulids in context of biodiversity conservation and fisheries management. Central Marine Fisheries Research Institute, 18: 138-141.

Gangan, S. S., Kumar, R., Ramteke, K. K., Kumar, A. P. and Jaiswar, A. K. 2016. Study of morphological variation discernible by multivariate analysis between the species of genus Setipinna (Teleostei: clupeiformes). Ecology Environment and Conservation, 22 (suppl.): 11-16.

Iwatsuki, I. 2013. Review of the Acanthopagrus latus complex (Perciform, Sparidae) with description of three new species from Indo-West pacific Ocean. Journal of Fish Biology, 83: 64-95. 


\section{Khamees et al.}

Krupp, F. and Müller, T. 1994. The status of fish populations in the northern Arabian Gulf two years after the 1991 war Gulf war oil spill. Courier Forsch-Inst Senckenberg, 10 (3): 67-75.

Kuronuma, K. and Abe, Y. 1972. Fishes of Kuwait. Kuwait Institute for Scientific Research,123pp.

Kuronuma, K. and Abe, Y. 1986.Fishes of Arabian Gulf. Kuwait Institute for Scientific Research, 357pp.

Li, C. and Orti, G. 2007. Molecular phylogeny of clupiformes (Actinopterygii) inferred from unclear and mitochondrial DNA sequences. Molecular phylogenetics and evolution, 44: 386-398.

Ma, C. Y., Ma, H.-Y., Ni, Y., Wang, W. and Ma, L. B. 2015. Molecular identification of the genus Thryssa based on DNA barcoding. Genetics and Molecular Research, 14(4): 18580-18586.

Nader, I. A. and Jawdat, S. Z. 1977. New records of fishes from Iraq. Bulltin of the Biological Research Centre, 8:73-87.

Randall, J. E. 1995. Coastal fishes of Oman. University of Hawaii. Press, Honolula: 439 pp.

Richards, W. J. 2008. Identification guide of the early life history stages of fishes from the waters of Kuwait stages in the Arabian gulf, Indian Ocean, Lucky Printing, 329 pp.

Richards, W. J. Al-Yamani, F. L. 2008. Identification guide of the early life history stages of fishes from the waters of Kuwait stages in the Arabian Gulf. Al-yamani, F. L. (ed.), Indian Ocean, Lucky Printing, 329pp.

Varghese, M., Thomas, V. T., Sreekumar, K. M., Suruthu, M. and Joseph, S. 2013. Large sized moustached Thryssa, Thryssa mystax (Bloch \& Schneider, 1801) recorded from Cochin coast in Kerala. Marine Fisheries Information Service T\& E., 217: 30.

Wangratana, T. 1987. Two new species of anchovies of genus Stolephorus (Engraulidae), with a key to species of Engraula, Encrasicholina and Stolephorus. American Museum Novitates, 2867: 1-8.

Whitehead, P. J. P., Nelson, G. T. and Wongratana, T. 1988. Clupeoid fishes of the world (Suborder. Clupeoidei). An annolated and illustrated catalogue of the herrings, sardines, pilchards, sparts, shads, anchovies and wolf-herrings. FAO Fisheries Synopsis, 7 (125), Part 2, 579pp.

Young, S. S., Chiu, T. S. and Shen, S. C. 1994. A revision of the family Engraulidae (Pisces) from Taiwan. Zoological Studies, 33(3): 217-227. 
Bull. Iraq nat. Hist. Mus.

December, (2018) 15 (2): 123-130

$$
\text { تو اجد و اعادة وصف لسمكة الثيغة }
$$

Thryssa setiroststris (Broussonet,1782) (Clupiforms,Engraulidae)

$$
\text { من المياه البحرية العراقية }
$$

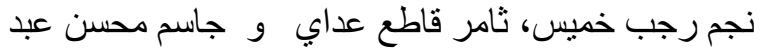

قسم الاسماك و الثروة البحرية، كلية الزراعة، جامعة البصرة، البصرة، العر اق

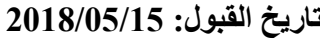

تاريخ الاستلام: 2018/03/19

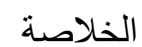

جمعت تسعة نماذج من سمكة الثيغة Broussonet, 178 Thryssa setiroststris

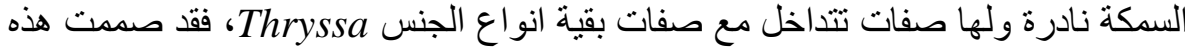
الدراسة التشخيصية التقصيلية لها.

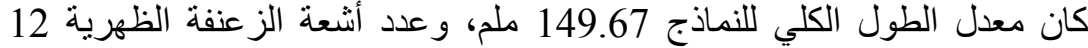

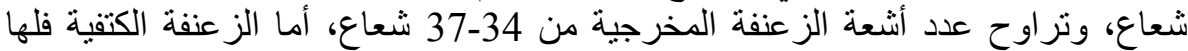

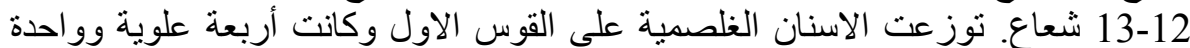
في الوسطو 10 سفلية.

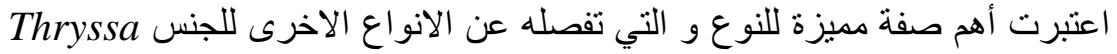
هي طول عظم الفك العلوي الذي يمتد ليصل الى الخلف من قمة الزعن عنفة الكتفية. 